\title{
A Rare Cause of Massive Pulmonary Hemorrhage: Invasive Actinomycosis
}

\section{Masif Pulmoner Hemorajinin Nadir bir Nedeni: Invaziv Aktinomikoz}

Bilge Yılmaz Kara', Mehmet Fatih İnecikli², Melek Memoğlu', Recep Bedir ${ }^{4}$, Uğur Kostakoğlu33, Songül Özyurt' ${ }^{1}$, Gökçen Sevilgen ${ }^{5}$, Şule Batçık' ${ }^{6}$ Ünal Şahin'

\section{Abstract}

Pulmonary actinomycosis is a severe clinical condition that may cause death if unrecognized. It may occur in patients who were previously healthy or may develop in patients with chronic immunosuppressant conditions. Presently described is a rare case of massive pulmonary hemorrhage with a related angioinvasive Actinomyces infection. A 52-year-old formerly immunocompetent man was admitted to the hospital due to blood-streaked sputum. A computed tomography image of the thorax taken after the patient's clinical status suddenly worsened revealed total collapse of the left lung. No tumoral lesion was observed, but extensive necrosis of the mucosa of both main bronchi with massive hemorrhage in the left main bronchus was noticed in an urgent bronchoscopy performed in the intensive care unit. A histopathological examination of the mucosal punch biopsy demonstrated aggregates of filamentous Grampositive organisms indicating Actinomyces infection.

\section{Özet}

Pulmoner aktinomikoz geç tanı konulduğunda ölümle sonuçlanabilecek bir durumdur. Daha çok immün yetmezliği olan bireylerde beklendiği gibi immünkompetan kişilerde de görülebileceği unutulmamalıdır. Bu yazıda invaziv pulmoner aktinomikoza bağlı masif pulmoner hemoraji gelişen nadir bir olgu sunulmuştur. Elli iki yaşında bilinen immünsupresif durumu olmayan erkek hasta ağızdan balgamla karışık kan gelmesi nedeni ile yatırıldı. Elektif bronkoskopi planlanan hastanın genel durumunda ani kötüleşme nedeni ile çekilen toraks bilgisayarlı tomografisinde sol akciğerde başvuruda olmayan total atelektazi saptandı. Yoğun bakım ünitesinde yapılan acil bronkoskopide sol ana broşta masif hemoraji ve her iki ana bronş mukozasında yaygın nekrotik görünüm izlendi. Alınan mukozal biyopsinin patolojik incelemesinde aktinomikozla uyumlu gram pozitif filamentöz bakteri agregatları izlendi. Bronşiyal arter kateterizasyonunda ekstravazasyon saptanan artere
'Department of Pulmonology, Recep Tayyip Erdogan University Faculty of Medicine, Rize, Turkey

${ }^{2}$ Department of Radiology, Recep Tayyip Erdogan University Faculty of Medicine, Rize, Turkey

${ }^{3}$ Department of Infectious Diseases, Recep Tayyip Erdogan University Faculty of Medicine, Rize, Turkey

${ }^{4}$ Department of Pathology, Recep Tayyip Erdogan University Faculty of Medicine, Rize, Turkey

${ }^{5}$ Department of Thoracic Surgery, Recep Tayyip Erdogan University Faculty of Medicine, Rize, Turkey

${ }^{6}$ Department of Anethesiology and Reanimation, Recep Tayyip Erdogan University Faculty of Medicine, Rize, Turkey

\author{
'Recep Tayyip Erdoğan Üniversitesi Tıp Fakültesi, Göğüs \\ Hastalıkları Anabilim Dalı, Rize \\ ${ }^{2}$ Recep Tayyip Erdoğan Üniversitesi Tıp Fakültesi, Radyoloji \\ Anabilim Dalı, Rize \\ ${ }^{3}$ Recep Tayyip Erdoğan Üniversitesi Tıp Fakültesi, Klinik Mik- \\ robiyoloji ve Enfeksiyon Hastalıkları Ana Bilim Dalı, Rize \\ ${ }^{4}$ Recep Tayyip Erdoğan Üniversitesi Tıp Fakültesi, Patoloi \\ Anabilim Dalı, Rize \\ ${ }^{5}$ Recep Tayyip Erdoğan Üniversitesi Tıp Fakültesi, Göğüs \\ Cerrahisi Anabilim Dalı, Rize \\ ${ }^{6}$ Recep Tayyip Erdoğan Üniversitesi Tıp Fakültesi, Anestezi ve \\ Reanimasyon Anabilim Dalı, Rize
}

Submitted (Başvuru tarihi): 03.10.2017 Accepted (Kabul tarihi): 29.12.2017

Correspondence (iletişim): Bilge Y,Imaz Kara, Department of Pulmonology, Recep Tayyip Erdogan University

Faculty of Medicine, Rize, Turkey

e-mail: drbilgeyilmaz@hotmail.com 
Selective embolization of a branch of the feeding artery was successful to control the hemorrhage, but necrotizing pneumonia emerged and the patient could not be discharged from the intensive care unit. He was later lost despite 40 days of treatment with intravenous penicillin- $G$ plus antifungal therapy. Pulmonary angioinvasive infections like actinomycosis must be kept in mind in the absence of bronchial carcinoma or other frequently encountered diseases in cases of massive pulmonary hemorrhage.

Key words: Actinomycosis, massive pulmonary hemorrhage, necrotising pneumonia. embolizasyon işlemi uygulandı. Ancak yerine gelişen bilateral nekrotizan pnömoni nedeni ile hastanın yoğun bakım takibine devam edildi. Hasta IV penisilin $G$ ve anti fungal tedaviye rağmen 40 günlük takip sonrasında kaybedildi. Masif pulmoner hemoraji olgularında sıklıkla kanama yapan hastalıklar ve tümoral lezyonların yokluğunda ayırıcı tanıda aktinomikoz gibi anjioinvaziv enfeksiyonlar düşünülmelidir.

Anahtar Sözcükler: Aktinomikoz, masif pulmoner hemoraji, nekrotizan pnömoni.
Actinomycosis is a chronic granulomatous infection of the lung parenchyma caused by Actinomyces species. These bacteria form aggregates of Gram-positive, branching, filamentous bacilli, usually found in hard, macroscopic grains of pus called "sulfur granules." Actinomyces spp. naturally reside on the mucosal surfaces of healthy individuals. They gain access to deeper tissues via trauma, surgical procedures, prosthetic devices, or foreign bodies, and manage to overcome the mucosal barrier and the immune system (1).

This report is a description of a case of pulmonary actinomycosis with massive pulmonary hemorrhage and fatal necrotizing pneumonia.

\section{CASE}

A 52-year-old male was admitted to the hospital for blood-streaked sputum, which had been present for several days. He had no history of a prediagnosed medical condition. He was a heavy smoker and habitual drinker. The patient was afebrile, with a heart rate of 78 beats/minute, a respiratory rate of 22 breaths/minute, and a blood pressure of $110 / 70 \mathrm{mmHg}$ on initial examination. His arterial oxygen saturation was 93\% while breathing room air. A general physical examination revealed cachexia and poor oral hygiene. Cardiovascular examination was normal. Thoracic auscultation on both sides of the lungs was normal, with no added breath sounds. Examinations of other organ systems were normal. His leucocyte count was 10,500 cells/ $\mu \mathrm{L}$ with a neutrophil predominance. The level of acute phase reactants was not elevated.

A computed tomography (CT) scan of the chest revealed a ground-glass opacity in the left upper lobe, indicating hemorrhage (Figure 1).

Prior to bronchoscopy, the patient experienced sudden chest pain and was transferred to the intensive care unit due to acute respiratory failure. His oxygen saturation decreased to $44 \%$. An urgent CT revealed total collapse of the left lung (Figure 2). A therapeutic bronchoscopy was performed and the active hemorrhage in the left main stem bronchus was terminated. Selective ventilation of the right lung with a double-lumen endotracheal tube provided adequate oxygenation, and arterial oxygen saturation of $96 \%$ was achieved. Selective cannulation and embolization of a branch of the truncus thyrocervicalis, which was responsible for the bleeding, was performed.

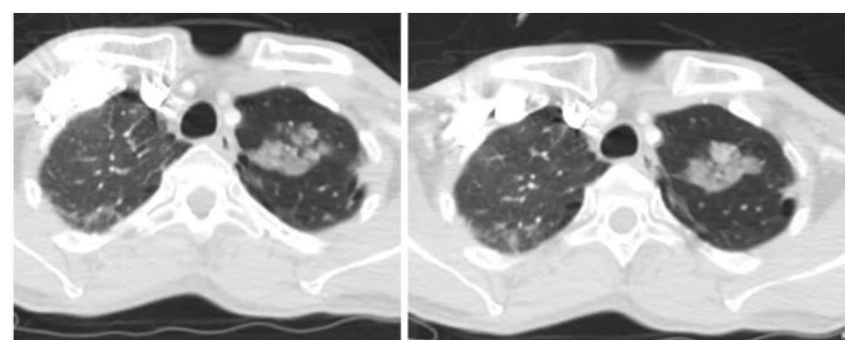

Figure 1: CT sections showing a groud glass opacity indicating hemorrhage in the left upper lobe
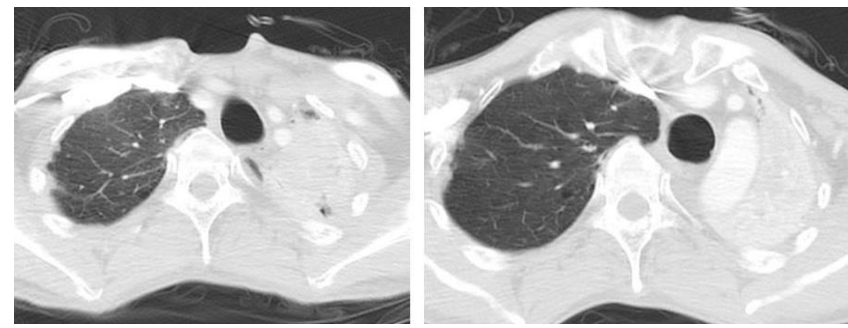

Figure 2: CT sections indicating total collapse of the left lung

A second diagnostic bronchoscopy revealed no tumoral lesion but extensive necrosis of the distal trachea and the main bronchi mucosa (Figure 3). A histopathological examination of the mucosal punch biopsy sample demonstrated aggregates of filamentous Gram-positive organisms, indicating actinomycosis (Figure 4). Microbiological culture isolates failed to identify the bacteriological species because the specimens were not incubated in anaerobic conditions. Bronchial lavage fluid was sent to the laboratory for both direct microscopic investigation 
and mycobacterial culture. In addition, polymerase chain reaction analysis for mycobacteria was performed. There was no bacterial growth on Löwenstein-Jensen medium after incubation for 45 days.
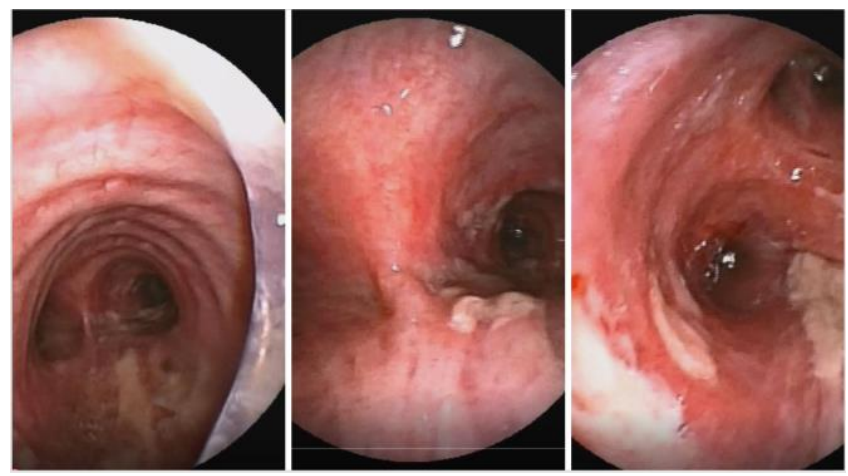

Figure 3: Bronchoscopic sections showing extensive necrosis of bronchial mucosa

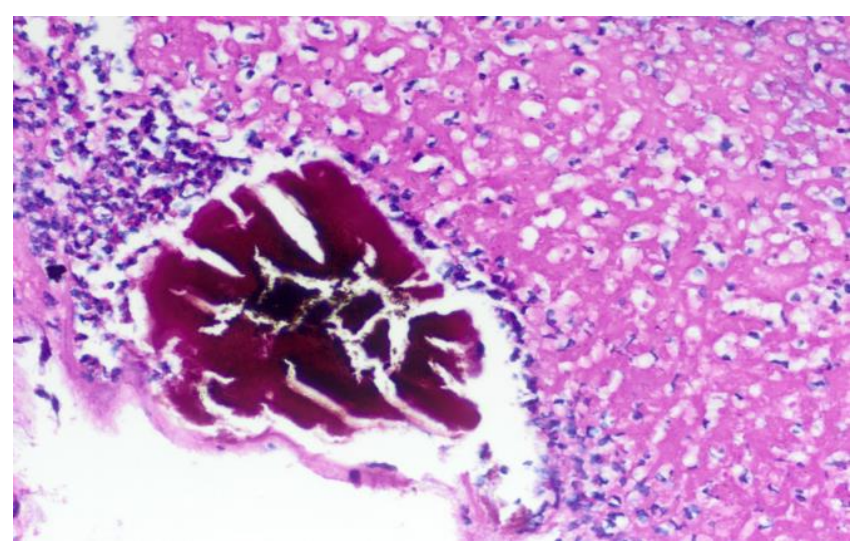

Figure 4: Aggregates of filamentous gram-positive organisms surrounded by inflammatory cells indicating Actinomycosis

Serum immunoglobulin levels were tested for HIV infection and tumor markers, and serum and urine analysis was examined for multiple myeloma. The departments of internal medicine and hematology were consulted. Further invasive investigations, such as a bone marrow biopsy, could not be performed due to the poor health status of the patient.

Despite intravenous administration of penicillin-G, necrotizing pneumonia developed in the opposite lung (Figure 5). Antifungal treatment was added for possible coexisting fungal infection. Surgery was not considered due to diffuse infiltrates in both lung fields. The patient was lost after 40 days of treatment in the hospital.

Written informed consent was obtained from the parents of the patient for this case presentation.

\section{DISCUSSION}

Actinomycosis is a rare cause of pulmonary infection and can be difficult to diagnose because its presentation may mimic tuberculosis (2) or lung cancer (3). Although individual papers describe infection of almost all tissues of human body, pulmonary actinomycosis represents approximately $15 \%$ of all cases (4). The most common clinical symptoms of pulmonary actinomycosis are chest pain, a productive cough, and hemoptysis. Subacute presentation of constitutional symptoms, like weight loss, fatigue, or fever, may also concur. In our case, the ground glass opacity in the left upper lobe, smoking history, and massive hemorrhage first suggested bronchogenic carcinoma in the differential diagnosis.

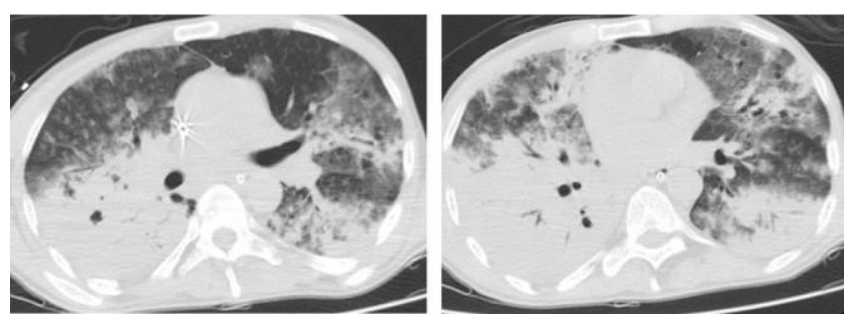

Figure 5: Bilateral consolidations showing necrotising pneumonia during treatment with penisillin $G$

Actinomyces infections may affect individuals of all age groups, even children, but the most commonly affected group is middle-aged males. Comorbid conditions like diabetes mellitus, smoking or alcohol abuse, poor oral hygiene or periodontitis, gastrectomy, foreign body aspiration like a fish bone, prosthetic devices like a bronchial stent, and healed pulmonary tuberculosis have been reported in the literature, but immunocompetent patients are more commonly affected unexpectedly. Alcoholics with poor oral hygiene, as in our case, are more susceptible to suppurative infections due to aspiration of oral flora, including Actinomyces spp. (5). A history of choking must be investigated when no other reason seems to be responsible for the condition.

The most common radiological findings are a mass, nodule, or consolidation on a chest CT (6). Almost all cases need pathological confirmation of actinomycosis from lung tissue. In a review article, invasive procedures were performed in 23 patients, of whom 14 underwent a wedge resection or lobectomy, 5 underwent a percutaneous transthoracic lung biopsy, and a bronchial biopsy was performed on 4 (7). Anaerobic cultures are required if there is a suspicion of Actinomyces infection, and collections must be made properly in order to identify the pathogens. In our case, the material collection and transport was not appropriate for anaerobic agents, so microbiological isolation of the Actinomyces species was not possible. 
Although Actinomyces spp. are susceptible to several antibiotics the most commonly used agent is parenteral penicillin- $G$, followed by the oral form. The average duration of treatment is 4 to 5 months (8). Diagnosis or treatment of pulmonary actinomycosis usually requires surgical intervention (9). Although surgery seems to be the best treatment modality (10), less invasive techniques, like embolization of the related artery in selected cases with hemorrhage, might be favorable due to fewer complications. Surgery was not the treatment of choice in the present case because the infection had affected many areas of the lung.

\section{CONCLUSION}

Although rare, pulmonary Actinomyces infection can be life threatening, especially in cases with massive hemorrhage. It must be kept in mind in the differential diagnosis of massive or non-massive hemoptysis or pulmonary hemorrhage, especially in the absence of a tumor or other common causes of bleeding.

\section{CONFLICTS OF INTEREST}

None declared.

\section{AUTHOR CONTRIBUTIONS}

Concept - B.Y.K., M.F.I., M.M., R.B., U.K., S.Ö., G.S., S..B., Ü.Ş.; Planning and Design - B.Y.K., M.F.I., M.M., R.B., U.K., S.Ö., G.S., S.B., Ü.Ş.; Supervision - B.Y.K., M.F.I., M.M., R.B., U.K., S.Ö., G.S., Ş.B., Ü.Ş.; Funding M.F.I., R.B.; Materials -; Data Collection and/or Processing - M.M., S.B.; Analysis and/or Interpretation B.Y.K., S.Ö.; Literature Review - B.Y.K., U.K., B.Y.; Writing - B.Y.K.; Critical Review - Ü.S., S.Ö.

\section{YAZAR KATKILARI}

Fikir - B.Y.K., M.F.I., M.M., R.B., U.K., S.Ö., G.S., Ş.B., Ü.S.; Tasarım ve Dizayn - B.Y.K., M.F.I., M.M., R.B., U.K., S.Ö., G.S., S.B., Ü.Ş.; Denetleme - B.Y.K., M.F.I., M.M., R.B., U.K., S.Ö., G.S., Ş.B., Ü.Ş.; Kaynaklar - M.F.I., R.B.;
Malzemeler - ; Veri Toplama ve/veya İşleme - M.M., Ş.B.; Analiz ve/veya Yorum - B.Y.K., S.Ö.; Literatür Taraması B.Y.K., U.K.; Yazıyı Yazan - B.Y.K.; Eleştirel İnceleme Ü.S., S.Ö.

\section{REFERENCES}

1. Könönen E, Wade WG. Actinomyces and related organisms in human infections. Clin Microbiol Rev 2015; 28:419-42. [CrossRef]

2. Varshney MK, Trikha $\mathrm{V}$, Khan SA. Actinomycosis or tuberculosis? A diagnostic dilemma. Scand J Infect Dis 2006; 38:378-81. [CrossRef]

3. Schweigert $M$, Dubecz A, Beron M, Ofner D, Stein HJ. Pulmonary infections imitating lung cancer: clinical presentation and therapeutical approach. Ir J Med Sci 2013; 182:73-80. [CrossRef]

4. Russo TA. Agents of actinomycosis. In: Mandell GL, ed. Principles and practice of infectious disease, 5th ed. Philadelphia: Elsevier, Churchill Livingstone, 1995:26452654.

5. Marra A, Hillejan L, Ukena D. Management of lung abscess. Zentralbl Chir 2015; 140:S47-53. [CrossRef]

6. Baik JJ, Lee GL, Yoo CG, Han SK, Shim YS, Kim YW. Pulmonary actinomycosis in Korea. Respirology 1999; 4: 31-5. [CrossRef]

7. Sun XF, Wang P, Liu HR, Shi JH. A Retrospective study of pulmonary actinomycosis in a single institution in China. Chin Med J 2015; 128:1607-10. [CrossRef]

8. Zhang $M$, Zhang $X-Y$, Chen $Y-B$. Primary pulmonary actinomycosis: a retrospective analyses of 145 cases in mainland China. Int J Tuberc Lung Dis 2017; $21: 825-31$ [CrossRef]

9. Endo S, Murayama F, Yamaguchi T, Yamamoto S, Otani $\mathrm{S}$, Saito $\mathrm{N}$, et al. Surgical considerations for pulmonary actinomycosis. Ann Thorac Surg 2002; 74:185-90. [CrossRef]

10. Rizzi A, Rocco G, Della Pona C, Robustellini M, Rossi G, Massera $F$, et al. Pulmonary actinomycosis: surgical considerations. Monaldi Arch Chest Dis 1996; 51:369-72. 